\title{
MENGUNGKAP TINDAK PIDANA KORUPSI DARI PEMBUKTIAN TERBALIK DAN LAPORAN HARTA KEKAYAAN PENYELENGGARA NEGARA (LHKPN)
}

\author{
Oleh : \\ Mangisi Simanjuntak,.SH.,MH \\ Dosen di Fakultas Hukum Universitas Suryadarma Jakarta Timur dan \\ Dosen di Fakultas Hukum UKI Jakarta serta \\ Mahasiswa Program Doktor Ilmu Hukum Universitas Borobudur Jakarta
}

\begin{abstract}
:
In a formal criminal law system of Indonesia, especially the Code of Criminal Procedure, it is understandable that the burden of proof regarding the existence of criminal offenses committed by the accused is on the Prosecution. In its development, the burden of proof which was originally in the hands of the Prosecution and then shifted to the defendant the burden particularly on corruption. In this case the defendant claimed that he played an active role not as a criminal. The defendant in the courtroom that will make all the burden of proof and if it can not prove the defendant was found guilty of committing a crime. This concept was later called by the reversal of the burden of proof (the reversal burdenof proof).
\end{abstract}

\section{PENDAHULUAN}

\section{A. Latar Belakang Masalah}

Tindak pidana korupsi sering sekali terjadi tanpa kita duga-duga di Kementerian/Lembaga, bahkan pelakunya pun sering kali diluar dugaan kita, kalau diselidiki dan ditelusuri harta kekayaan tiap-tiap penyelenggara/aparat negara dan pegawai swasta kemungkinan besar ada sebagian dari kekayaannya didapatkan bukan dari penghasilan yang sah. Sering kita terheran-heran dibuatnya, manakala ada penyelenggara atau pegawai swasta kekayaannya berlimpah tidak seimbang dengan penghasilannya atau sumber penambahan kekayaannya. Misalnya saja seorang pegawai negeri golongan IVa yang bekerja di Kementerian tetapi sudah bisa punya rumah mewah, mobil bagus, bahkan menyekolahkan anaknya di luar negeri, belum lagi kalau diselidiki berapa banyak uangnya di bank, tidak sesuai antara penghasilannya dengan pengeluarannya.

Untuk itulah tiap-tiap penyelenggara / aparat negara baik sipil maupun militer dan pegawai swasta diwajibkan menyampaikan dengan jujur Laporan Harta 
Kekayaan Penyelenggara Negara (LHKPN) setiap tahunnya. Apabila ada harta kekayaan yang fantastis yang tidak sesuai dengan penghasilan penyelenggara/aparat negara tersebut maka harus diteruskan dengan penyelidikan yang pada akhirnya bisa dilakukan proses hukum dan apabila ada ditemukan harta kekayaannya yang tidak dilaporkan sebelumnya maka harta kekayaan tersebut dapat dirampas untuk negara. Penemuan harta kekayaan penyelenggara negara yang fantastis dan harta kekayaan yang tidak pernah dilaporkan ini dapat menjadi jembatan sekaligus menjadi pintu untuk mengungkap suatu tindak pidana korupsi. Penemuan harta kekayaan tersebut seharusnya ditindaklanjutkan dengan pembalikan beban pembuktian (pembuktian terbalik) oleh penyelenggara negara, artinya bahwa penyelenggara negara tersebut wajib membuktikan dari mana diperoleh harta kekayaannya yang fantastis dan harta kekayaannya yang tidak dilaporkan tersebut.

Dalam pemberantasan korupsi telah banyak dilakukan upaya-upaya untuk mengungkap kasus tersebut di muka pengadilan bahkan pelaku korupsi pun sudah banyak yang dihukum berat, hanya saja rakyat merasakan masih banyak tindak pidana korupsi terjadi di tengahtengah masyarakat. Pemerintah sudah membuka selebar-lebarnya dengan mempersilahkan aparat penegak hukum membongkar kasus korupsi demi menyelamatkan uang negara dan menghindari rakyat menjadi miskin. Pemerintah ingin lebih banyak lagi mengungkap kasus-kasus korupsi. ${ }^{1}$ Pengungkapan kasus-kasus korupsi itu dilakukan dengan pembuktian terbalik.

Dalam perkembangannya beban pembuktian yang semula berada di tangan Jaksa Penuntut Umum kemudian bergeser menjadi beban terdakwa. Dalam hal ini terdakwa berperan aktif menyatakan bahwa dirinya bukan sebagai pelaku tindak pidana korupsi. Terdakwa di depan sidang pengadilan yang akan menyiapkan segala beban pembuktian dan bila tidak dapat membuktikan, terdakwa dinyatakan bersalah melakukan tindak pidana. Konsep inilah yang kemudian disebut dengan pembalikan beban pembuktian (the reversal burden of proof). ${ }^{2}$

Pada dasarnya undang-undang tindak pidana korupsi menganut sistem pembalikan beban pembuktian (pembuktian terbalik) sebagaimana dalam ketentuan Pasal 12B, Pasal 37, Pasal 37A, dan Pasal 38B. Secara teoritis terdapat dua alasan yang dapat dikemukakan mengapa pembalikan beban pembuktian diterapkan dalam tindak pidana korupsi. Pertama, alasan pendekatan historis. Keberadaan pasal-pasal suap yang diintroduksikan dari KUHP kedalam Pasal 5 sampai dengan pasal 13 Undang-Undang Nomor 31 Tahun 1999, selama ini hanya sebagai pasal tidur yang tidak memiliki makna. ${ }^{3}$

Dalam pasal 37 Undang-Undang Nomor 31 Tahun 1999 tentang

1 . Monang Siahaan, Korupsi, Penyakit Sosial yang Mematikan (Jakarta : PT. Elex Media Komputindo 2013) hlm 97

2 . Mahrus Ali, Asas, Teori \& Praktek, Hukum

Pidana Korupsi (Jogjakarta : UII Press, 2013) hlm 76.

3 . Ibid hlm 78 
Pemberantasan Tindak Pidana

Korupsi dinyatakan bahwa :

(1) Terdakwa mempunyai hak untukmembuktikan bahwa ia tidak melakukan tindak pidana korupsi.

(2) Dalam hal terdakwa dapat membuktikan bahwa ia tidak melakukan tindak pidana korupsi, maka keterangan tersebut dipergunakan sebagai hal yang menguntungkan baginya.

(3) Terdakwa wajib memberikan keterangan tentang seluruh harta bendanya dan harta benda setiap orang atau korporasi yang diduga mempunyai hubungan dengan perkara yang bersangkutan.

(4) Dalam hal terdakwa tidak dapat membuktikan tentang kekayaan yang tidak seimbang dengan penghasilannya atau sumber penambah kekayaan, maka keterangan tersebut dapat dipergunakan untuk memperkuat alat bukti yang sudah ada bahwa terdakwa telah melakukan tindak pidana korupsi.

(5) Dalam keadaan sebagaimana dimaksud dalam ayat (1), ayat (2), ayat (3), dan ayat (4), penuntut umum berkewajiban untuk membuktikan dakwaannya.

Kedua, alasan pendekatan komparatif yuridis metode yang dipergunakan untuk mengaktifkan ketentuan atau pasal suap ini adalah dengan memperkenalkan system mekanisme pelaporan. Dengan adanya system pelaporan atau pemberian sesuatu kepada penyelenggara negara maka penyelenggara negara bertindak pro- aktif, begitu pula dengan aparatur penegak hukum yang bertanggung jawab atas program pemberantasan tindak pidana korupsi. ${ }^{4}$ Yang sering terjadi dalam suatu tindak pidana korupsi adalah bahwa aparat penyelenggara negara mengambil sebagian dari anggaran proyek ataupun pembangunan untuk memperkaya dirinya, orang lain maupun korporasi. Sedangkan untuk pidana suap atau gratifikasi adalah pengusaha, pihak swasta atau siapapun yang memberikan sejumlah uang kepada aparat penyelenggara negara demi memperlancar urusannya.

Pembalikan beban pembuktian ini dimaksudkan apabila seseorang terdakwa tidak dapat membuktikan harta kekayaannya di dapat dari penghasilannya yang sah maka pembalikan beban pembuktian ini dapat merupakan suatu langkah/cara untuk mengungkapkan bahwa telah terjadi tindak pidana korupsi. Disisi lain, meskipun seorang terdakwa dapat membuktikan tentang asal-asul kekayannya bukan berarti si terdakwa tidak terbukti telah melakukan tindak pidana korupsi karena Jaksa Penuntut Umum tetap punya hak untuk mendakwa berdasarkan bukti-bukti yang ada. Terdakwa tetap diproses hukum dan apabila terbukti telah melakukan tindak pidana korupsi maka pengadilan dapat memvonis si terdakwa daan kemudian si terdakwa akan menjadi terpidana.

Dalam penjelasan pasal 37 Undang-Undang Nomor 31 Tahun 1999 tentang Pemberantasan Tindak

\footnotetext{
4 . Ibid hlm 78 .
} 
Pidana Korupsi dinyatakan bahwa ketentuan ini merupakan suatu penyimpangan dari ketentuan Kitab Undang-Undang Hukum Acara Pidana (KUHAP) yang menentukan bahwa Jaksa yang wajib membuktikan dilakukannya tindak pidana, bukan terdakwa. Menurut ketentuan ini terdakwa dapat membuktikan bahwa ia tidak melakukan tindak pidana korupsi. Apabila terdakwa dapat membuktikan hal tersebut bukan berarti bahwa ia tidak terbukti melakukan korupsi, sebab penuntut umum masih tetap berkewajiban untuk membuktikan dakwaannya. Ketentuan pasal ini merupakan pembuktian terbalik yang terbatas, karena jaksa masih tetap wajib membuktikan dakwaannya.

\section{B. Perumusan Masalah}

$$
\begin{array}{llr}
\text { Berdasarkan } & \text { latar } & \text { belakang } \\
\text { permasalahan } & \text { tersebut } & \text { diatas, } \\
\text { diidentifikasikan } & \text { rumusan } & \text { penulisan } \\
\text { sebagai berikut: } & &
\end{array}
$$

1. Mengapa tindak pidana korupsi akhir-akhir ini semakin banyak terjadi di Indonesia?

2. Sejauhmana efektivitas pembalikan beban pembuktian (pembuktian terbalik) dan Laporan Harta Kekayaan Penyelenggara Negara dapat mengungkap suatu tindak pidana korupsi ?

\section{Maksud dan Tujuan Penulisan}

\section{Maksud Penulisan}

Maksud dari penulisan makalah ini diharapkan agar para pembaca mengetahui mengapa tindak pidana korupsi akhir-akhir ini semakin banyak terjadi di
Indonesia dan sejauhmana efektivitas pembalikan beban pembuktian (pembuktian terbalik) serta laporan harta kekayaan penyelenggara negara dapat mengungkap suatu tindak pidana korupsi.

\section{Tujuan Penulisan}

Sesuai dengan perumusan masalah yang telah diuraikan di atas, maka penulisan ini bertujuan:

a. Untuk mengetahui dan mengkaji mengapa tindak pidana korupsi akhir-akhir ini semakin banyak terjadi di Indonesia?

b. Untuk mengetahui dan mengkaji sejauhmana efektivitas pembalikan beban pembuktian (pembuktian terbalik) dan laporan harta kekayaan penyelenggara negara (LHKPN) dapat mengungkap suatu tindak pidana korupsi.

\section{Kerangka konseptual ${ }^{5}$}

Pembuktian terbalik sudah diatur pada pasal 37 Undang-Undang Nomor 31 Tahun 1999 tentang Pemberantasan Tindak Pidana Korupsi dan Laporan Harta Kekayaan Penyelenggara Negara (LHKPN) juga sudah diatur dalam Undang-Undang Nomor 28 Tahun 1999 tentang Penyelenggara Negara yang Bersih dan Bebas dari Korupsi, Kolusi, dan Nepotisme. Kedua hal tersebut dibuat dalam suatu undang-undang dimaksudkan untuk mengurangi terjadinya tindak pidana korupsi

5. Ade Saptomo, Pokok-Pokok Metodologi, Penelitian Hukum dan Empiris Murni, Sebuah Alternatif (Jakarta. Penerbit : Universitas Trisakti). Hlm 52 . 
bahkan diharapkan mengkikis habis di setiap Kementerian dan Lembaga.

\section{E. Metodologi Penulisan.}

\section{Pendekatan.}

Penulisan dilakukan dengan menggunakan pendekatan perundang-undangan (statute approach) yaitu dilakukan dengan menelaah semua undang-undang dan peraturan yang bersangkut paut dengan isu hukum yang sedang ditangani. Seiring dengan itu dikaitkan dengan disiplin ilmu hukum, penulisan ini termasuk penulisan yuridis normatif. ${ }^{6}$

\section{Sumber Bahan Hukum}

Adapun sumber bahan hukum yang digunakan dalam penulisan ini yaitu :

a. Bahan hukum primer (peraturan perundang-undangan $)^{7}$ yaitu :

1) Undang-Undang Nomor Nomor 31 Tahun 1999 tentang Pemberantasan Tindak Pidana Korupsi.

2) Undang-Undang Nomor Undang-Undang Nomor 28 Tahun 1999 tentang Penyelenggara Negara yang Bersih dan Bebas dari Korupsi, Kolusi, dan Nepotisme.

3) Undang-Undang Nomor 20 Tahun 2001 tentang Perubahan atas UndangUndang Nomor 31 Tahun

${ }^{6}$. http://rulhome.blog.com/2010/04/11/contohmetode-penelitian-normatif-dengan-penelitianempiris/ di download tgl 19 Mei 2015 pukul 18.16 wib.

${ }^{7}$.Dyah Ochtorina Susanti dan A'an Efendi.Opcit. hlm 53
1999 tentang Pemberantasan

Tindak Pidana Korupsi

b. Bahan hukum sekunder yaitu bahan yang memberikan tinjauan yang luas tentang pokok persoalan dan mengidentifikasi perundangundangan, regulasi, ketentuanketentuan pokok lainnya. ${ }^{8}$

c. Bahan hukum tersier yaitu bahan-bahan yang memberikan petunjuk / penjelasan terhadap bahan hukum primer dan sekunder misalnya website dari internet. ${ }^{9}$

\section{DEFENISI - DEFENISI DAN TEORI HUKUM}

\section{A. Defenisi - Defenisi :}

\section{Tindak Pidana Korupsi}

\section{a. Asal Kata dan Pengertian Korupsi}

Istilah korupsi yang telah diterima dalam perbendaharaan kata bahasa Indonesia itu, disimpulkan oleh Poerwadarminta dalam Kamus Umum Bahasa Indonesia; Korupsi ialah perbuatan yang buruk seperti penggelapan uang, penerimaan uang sogok. Di Malaysia terdapat juga peraturan anti korupsi. Tidak dipakai kata korupsi melainkan dipakai istilah resuah yang artinya sama dengan korupsi. $\mathrm{Di}$ Indonesia selalu menggunakan kata korupsi meskipun korupsi dalam bahasa

${ }^{8}$.Ibid hlm 87

${ }^{9}$. Ibid hlm 139. 
Indonesia bisa juga disebut dengan istilah rasuah. Dengan pengertian korupsi secara harafiah itu ditarik suatu kesimpulan bahwa sesungguhnya korupsi itu sebagai suatu istilah yang sangat luas artinya. ${ }^{10}$

\section{b. Definisi Tindak Pidana \\ Korupsi}

Tindak pidana korupsi sebagaimana diatur pada pasal 2 dan 3 dan penjelasannya Undang-Undang Republik Indonesia Nomor 31 Tahun 1999 tentang Pemberantasan Tindak Pidana Korupsi yaitu :

1) Perbuatan yang dilakukan seseorang secara melawan hukum untuk memperkaya diri sendiri atau orang lain atau suatu korporasi yang dapat merugikan keuangan negara atau perekonomian Negara. Korporasi adalah kumpulan orang dan atau kekayaan yang terorganisasi baik merupakan badan hukum maupun bukan badan hukum.

2) Perbuatan yang dilakukan seseorang secara melawan hukum dengan tujuan menguntungan diri sendiri atau orang lain atau suatu korporasi, menyalahgunakan kewenangan, kesempatan atau sarana yang ada

${ }^{10}$. Jur. Andi Hamzah, Pemberantasan Korupsi melalui Hukum Pidana Nasional dan Internasional, (Jakarta : PT Rajagrafindo Persada), 2005), hlm. 4-5. padanya karena jabatannya atau kedudukan yang dapat merugikan keuangan Negara atau perekonomian Negara.

$\begin{array}{lcr}\text { Yang } & \text { dimaksud } & \text { dengan } \\ \text { secara } & \text { melawan } & \text { hukum } \\ \text { mencakup } & \text { perbuatan } & \text { melawan }\end{array}$ hukum dalam arti formil maupun dalam arti materiil, yakni meskipun perbuatan tersebut tidak diatur dalam peraturan perundang-undangan namun apabila perbuatan tersebut dianggap tercela karena tidak sesuai dengan rasa keadilan atau norma-norma kehidupan social dalam masyarakat, maka perbuatan tersebut dapat dipidana. Dalam ketentuan ini, kata "dapat" sebelum frasa "merugikan keuangan atau perekonomian Negara" menunjukkan bahwa tindak pidana korupsi merupakan delik formil, adanya tindak pidana korupsi cukup dengan dipenuhinya unsureunsur perbuatan yang sudah dirumuskan bukan dengan timbulnya akibat.

Yang dimaksud dengan "keadaan tertentu" dalam ketentuan ini dimaksudkan sebagai pemberatan bagi pelaku tindak pidana korupsi apabila tindak pidana tersebut dilakukan pada waktu Negara dalam keadaan bahaya sesuai undang-undang yang berlaku, pada waktu terjadi bencana alam nasional, sebagai pengulangan tindak pidana korupsi, atau pada waktu 
Negara dalam keadaan krisis ekonomi dan moneter.

\section{c. Peringkat Korupsi di Indonesia} diantara Negara-Negara di Asia Pasifik.

Korupsi yang telah menjadi "karakter" pada masa Orde Baru hingga rezim pemerintahan saat ini telah menjadi penghambat utama dalam menciptakan praktik pemerintahan yang baik (good governance). Sementara demokrasi yang bertujuan untuk kesejahteraan rakyat pada kenyataannya hanya dijalankan sebatas formalisme procedural. Bahkan, telah menjadi sekedar pembungkus kejahatankejahatan tindak pidana korupsi yang dilakukan oleh pejabatpejabat publik, dari tingkat pusat sampai paling rendah. Kondisi ini dalam banyak hal juga terjadi pada organisasiorganisasi swasta atau nonpemerintah.

Fakta terkini yang terungkap menunjukkan bahwa kecenderungan korupsi di Indonesia kian meningkat. Perkara korupsi yang terungkap dalam Semester I pada tahun 2010 misalnya sebanyak 176 kasus. Sebanyak 441 orang ditetapkan sebagai tersangka dan kerugian negara akibat korupsi itu sekitar Rp 2,1 triliun. Pada periode yang sama tahun 2009 hanya ada 86 kasus korupsi yang disidik, 217 tersangka, dan kerugian negara pada tahun 2009 sekitar Rp. 1,17 triliun. Temuan ini menunjukkan bahwa upayaupaya pencegahan dan pemberantasan korupsi masih sebatas pada formalitas dan bahkan slogan. Penanganan yang dilakukan oleh institusiinstitusi yang diberi kewenangan untuk melakukan pemberantasan korupsi belum sampai pada akar persoalannya.

Fakta lain yang tidak bisa dipungkiri adalah temuan yang dilakukan oleh sebagian lembaga riset seperti PERC (Political and Economic Risk Consultancy) menempatkan Indonesia masih berada dalam urutan pertama negara paling korup di Asia Pasifik. Adapun urutan negara-negara terkorup di Asia Pasifik yaitu : Indonesia : Grade 8.16, Vietnam : Grade 7.91, Philippines : Grade 7.80, Thailand : Grade 7.64, China : Grade 7.58, India : Grade 6.76, Malaysia : Grade 6.13, Taiwan : Grade 5.91, Korea Selatan: Grade 5.44, Macao: Grade 4.78, Hong Kong : Grade 3.13, Jepang: Grade 3.01, Singapore : Grade 1.3. ${ }^{11}$.

\section{Pembuktian Terbalik}

\section{a. Defenisi Pembuktian Terbalik}

Undang-Undang Nomor 31 Tahun 1999 tentang Pemberantasan Tindak Pidana Korupsi pada penjelasan umum menyatakan bahwa pembuktian terbalik bersifat terbatas atau

11 . Sukron Kamil, Korupsi dan Integritas Dalam Ragam Perspektif, (Jakarta : Pusat Studi IndonesiaArab-PSIA), 2013, hlm. 4-5. 
berimbang yakni terdakwa mempunyai hak untuk membuktikan bahwa ia tidak melakukan tindak pidana korupsi dan wajib memberikan keterangan tentang seluruh harta bendanya dan harta benda istri atau suami, anak, dan harta benda setiap orang atau korporasi yang diduga mempunyai hubungan dengan perkara yang bersangkutan, dan penuntut umum tetap berkewajiban membuktikan dakwaannya.

\section{b. Pembuktian Terbalik dalam} Tindak Pidana Korupsi.

Dalam system hukum pidana formil Indonesia khususnya Kitab Undang-Undang Hukum Acara Pidana, sudah dimaklumi bahwa beban pembuktian mengenai ada tidaknya tindak pidana yang dilakukan oleh terdakwa terletak pada Jaksa Penuntut Umum. Dalam perkembangannya, khususnya pada tindak pidana korupsi beban pembuktian yang semula ditangan Jaksa Penuntut Umum kemudian bergeser menjadi beban terdakwa. Dalam hal ini terdakwa berperan aktif menyatakan bahwa dirinya bukan sebagai pelaku tindak pidana. Terdakwa di depan sidang pengadilan yang akan menyiapkan segala beban pembuktian dan bila tidak dapat membuktikan, terdakwa dinyatakan bersalah melakukan tindak pidana. Konsep inilah yang kemudian disebut dengan pembalikan beban pembuktian (the reversal burdenof proof).

Ketentuan mengenai pembuktian terbalik perlu ditambahkan dalam undangundang Nomor 31 Tahun 1999 tentang Pemberantasan Tindak Pidana Korupsi sebagai ketentuan yang bersifat "Premium remidium" dan sekaligus mengandung sifat prevensi khusus terhadap pegawai negeri sebagaimana dimaksud dalam pasal 1 angka 2 , atau terhadap penyelenggara negara sebagaimana dimaksud dalam pasal 2 Undang-Undang Nomor 28 Tahun 1999 tentang Penyelenggara Negara yang Bersih dan Bebas dari Korupsi, Kolusi, dan Nepotisme.

\section{Laporan Harta Kekayaan Penyelenggara Negara (LHKPN)}

a. Defenisi

Penyelenggara Negara.

Menurut Undang-Undang Nomor 28 Tahun 1999 tentang Penyelenggara Negara Yang Bersih dan Bebas dari Kolusi, Korupsi dan Nepotisme, yang dimaksud dengan Penyelenggara Negara adalah Pejabat Negara yang menjalankan fungsi eksekutif, legislatif, atau yudikatif, dan pejabat lain yang funsi dan tugas pokoknya berkaitan dengan penyelenggaraan negara sesuai dengan ketentuan peraturan perundang-undangan yang berlaku. Penyelenggara Negara meliputi: Pejabat Negara pada Lembaga Tertinggi 
Negara, Pejabat Negara pada

Lembaga Tinggi Negara,

Menteri, Gubernur, Hakim,

Pejabat negara yang lain sesuai

dengan ketentuan peraturan

perundang-undangan yang

berlaku dan Pejabat lain yang

memiliki fungsi strategis dalam

kaitannya dengan

penyelenggaraan negara sesuai

dengan ketentuan peraturan perundangan.

\section{b. Definisi Laporan Harta Kekayaan Penyelenggara Negara (LHKPN)}

Laporan Harta Kekayaan Penyelenggara Negara untuk selanjutnya disebut (LHKPN), adalah daftar seluruh Harta Kekayaan Penyelenggara Negara, yang dituangkan dalam formulir LHKPN yang ditetapkan oleh KPK sebagaimana yang diatur dalam Keputusan KPK Nomor : KEP07/KPK/02/2005.Penyam paian LHKPN ini juga diharuskan bagi pejabat Bank pada BUMN dan BUMD. ${ }^{12}$

\section{c. Komisi Pemeriksa Kekayaan} Penyelenggara Negara (Komisi Pemeriksa)

Komisi Pemeriksa Kekayaan Penyekenggara Negara yang selanjutnya disebut Komisi Pemeriksa adalah lembaga independen yang bertugas untuk memeriksa kekayaan penyelenggara Negara untuk mencegah korupsi, kolusi dan

${ }^{12} \cdot$ http://hukum

perbankan.blogspot.co.id/2009/07/laporan-hartakekayaan-penyelenggara $24 . \mathrm{html}$, di download pada tanggal 06 April 2016 pukul 16.13 wib. nepotisme. Komisi Pemeriksa mempunyai tugas dan wewenang untuk melakukan pemeriksaan terhadap kekayaan Penyelenggara Negara.

\section{d. Tugas dan wewenang Komisi} Pemeriksa :

1) Melakukan pemantauan dan klarifikasi atas harta kekayaan Penyelenggara Negara;

2) Meneliti laporan atau pengaduan masyarakat, lembaga swadaya masyarakat, atau instansi pemerintah tentang dugaan adanya korupsi, kolusi, dan nepotisme dari para Penyelenggara Negara;

3) Melakukan penyelidikan atas inisiatif sendiri mengenai harta kekayaan Penyelenggara Negara berdasarkan petunjuk adanya korupsi, kolusi, dan nepotisme terhadap Penyelenggara Negara yang bersangkutan;

4) Mencari dan memperoleh bukti-bukti, menghadirkan saksi-saksi untuk penyelidikan Penyelenggara Negara yang diduga melakukan korupsi, kolusi, dan nepotisme atau meminta dokumen-dokumen dari pihak-pihak yang terkait dengan penyelidikan harta kekayaan Penyelenggara Negara yang bersangkutan;

5) Jika dianggap perlu, selain meminta bukti kepemilikan sebagian atau seluruh harta kekayaan Penyelenggara Negara yang diduga 
diperoleh dari korupsi, kolusi

dan nepotisme selama menjabat sebagai

Penyelenggara Negara, juga meminta pejabat yang berwenang membuktikan dugaan tersebut sesuai dengan ketentuan peraturan perundang-undangan yang berlaku.

Pemeriksaan kekayaan Penyelenggara Negara sebagaimana diatas, dilakukan sebelum, selama, dan setelah yang bersangkutan menjabat. ${ }^{13}$ Artinya, Harta kekayaan penyelenggara Negara tersebut dihitung jumlahnya sebelum dia menjabat kemudian pada saat menjabat juga dipantau penambahan harta kekayaannya yang lebih penting lagi setelah selesai menjabat berapa banyak pertembahan jumlah harta kekayaan si penyelenggara Negara tersebut.

\section{B. Teori Hukum}

Teori hukum yang digunakan dalam penulisan makalah ini adalah teori kewajiban dan paksaan. Salah satu hakikat dari hukum adalah hukum dapat dipaksakan berlakunya bila perlu dengan campur tangan negara. Karena itu, dalam hukum itu sendiri terdapat unsur kewajiban yang harus dilaksanakan oleh setiap orang yang tunduk kepada hukum yang bersangkutan. Sebagai ekuivalensi dari kewajiban, hukum juga menyediakan dan negara menjamin hak-hak tertentu bagi warga negara. Paksaan,

13.

file:///C:/Users/Ban 6/Downloads/UU NO 28 1999.PDF, di download tanggal 13 April 2016 pukul 13.33 wib. kewajiban, dan penjamin hak terhadap warga masyarakat dimaksudkan agar suatu system keteraturan yang dirancang oleh hukum dapat berjalan dengan baik dan tertib, sehingga muncul konsep ketertiban hukum. ${ }^{14}$

Berlakunya suatu ketertiban hukum dapat dipaksakan dengan sanksi-sanksi tertentu. Karena hukum dapat dipaksakan berlakunya, maka suatu ketertiban hukum juga merupakan ketertiban dari paksaanpaksaan. Ini pula yang membedakan antara ketertiban hukum dengan ketertiban sosial lainnya. ${ }^{15}$

Dengan menggunakan teori ini, berdasarkan pasal 37 Undang-Undang Nomor 31 Tahun 1999 dan juga pasal 37 Undang Nomor 20 Tahun 2001 tentang Pemberantasan Tindak Pidana Korupsi, dalam suatu perkara tindak pidana korupsi dipaksakan kepada si terdakwa untuk membuktikan seluruh harta kekayaannya dan berdasarkan pasal 5 ayat (3) Undang-Undang Nomor 28 Tahun 1999 tentang Penyelenggara Negara yang Bersih dan Bebas dari Korupsi, Kolusi, dan Nepotisme, merupakan suatu kewajiban dan paksakan kepada penyelenggara negara untuk melaporkan dan mengumumkan kekayaannya sebelum dan setelah menjabat. Tidak ada alasan bagi terdakwa dan penyelenggara Negara untuk tidak mematuhi undang-undang tersebut diatas.

Pada pasal 5 ayat (4) UndangUndang Nomor 28 Tahun 1999 juga

\footnotetext{
14. Munir Fuady, Teori-Teori Besar (Grand Theory) Dalam Hukum (Jakarta : Kencana Prenadamedia Group, 2013) hlm 105

15 . Ibid hlm 106.
} 
dinyatakan bahwa penyelenggara negara berkewajiban untuk tidak melakukan perbuatan korupsi, kolusi, dan nepotisme, jadi apabila ada penyelenggara Negara yang melakukan tindak pidana korupsi, selain melanggar undang-undang tentang pemberantasan tindak pidana korupsi juga melanggar undangundang tentang Penyelenggara Negara yang Bersih dan Bebas dari Korupsi, Kolusi, dan Nepotisme.

Oleh karena itu, apabila ada penyelenggara negara yang melakukan tindak pidana korupsi, sudah seharusnyalah di hukum berat karena selain telah melanggar undangundang pemberantasan tindak pidana korupsi juga telah melanggar undangundang Penyelenggara Negara yang Bersih dan Bebas dari Korupsi, Kolusi, dan Nepotisme.

\section{PEMBAHASAN}

\section{A. Tindak Pidana Korupsi Merajalela di Indonesia.}

Akhir-akhir ini sering kita ketahui banyak sekali terjadi tindak pidana korupsi di negara tercinta ini. Ditangkapnya anggota DPRD DKI Jakarta dengan Operasi Tangkap Tangan (OTT) karena diduga menerima suap Rancangan Peraturan Daerah (Raperda Reklamasi) seakanakan menambah banyak jumlah pelaku tindak pidana korupsi. Sebelumnya Ketua PSSI non aktif telah ditetapkan sebagai tersangka korupsi dana hiba Kadin Jawa Timur dan sampai saat ini tersangka korupsi hiba tersebut masih buron dan telah menjadi buronan Interpol. ${ }^{16}$ Sebelumnya juga ada anggota DPRRI Dewi Yasin Limpo yang ditangkap oleh KPK karena diduga melakukan tindak pidana korupsi, menerima suap sebesar Sin\$177.700 (Rp 1,7 miliar) terkait proyek pengembangan pembangkit listrik tenaga mikro hidro di Kabupaten Deiyai, Papua, TA $2016 .{ }^{17}$

Negeri ini seakan-akan telah dikepung koruptor, korupsi telah merajalela dimana-mana, korupsi terjadi hampir disetiap Kementerian /Lembaga dan instansi-instansi baik instansi pemerintah (sipil dan militer) maupun instansi swasta. Korupsi belum ada matinya sehingga dapat dikatakan bahwa korupsi itu penyakit sosial yang mematikan. Mematikan maksudnya membuat mati kehidupan sosial masyarakat. Pola dan akar korupsi telah tercipta dan menggurita disetiap kegiatan yang mengeluarkan/ memerlukan biaya oleh aparat penyelenggara Negara. Oligarki dan korupsi berjalan bergandengan yang akan merusak sendi-sendi ekonomi dan sendi-sendi kehidupan sosial politik di Indonesia.

Mengapa tindak pidana korupsi banyak terjadi di Indonesia akhirakhir ini ? Perlu diketahui bahwa tindak pidana korupsi itu dapat dibedakan menjadi 3 (tiga) jenis yaitu korupsi karena kebutuhan (corruption by need), korupsi karena kesempatan (corruption by opportunities) dan korupsi karena keserakahan (corruption by

\footnotetext{
${ }^{16}$. Surat Kabar Kompas Tgl 31 Maret 2016 hlm 1. 17 . https://m.tempo.co/read/news/2015/10/21/06371 1709/begini-kronologi-kpk-tangkap-dewie-yasinlimpo, di download pada tanggal 07 April 2016 pukul $07.51 \mathrm{wib}$.
} 
greed). Ketiga tindak pidana korupsi itu terjadi disebabkan aspek moral, aspek dorongan diri sendiri dan aspek rangsangan dari luar.

Aspek moral terjadi karena adanya moral yang tidak baik dari pelaku, perbuatan korupsi dilakukan untuk memperkaya dirinya, keluarganya, kelompok atau golongannya sendiri. Dengan mendasarkan pada motif kekayaan pribadi atau golongan ini, dapatlah dipahami jika korupsi bisa terdapat dimana-mana dan bisa terjadi kapan saja karena masalah korupsi selalu terkait dengan motif yang ada pada setiap insan manusia untuk mendapatkan keuntungan pribadi atau golongan. Ada juga yang berpendapat ada tiga indikasi yang menyebabkan meluasnya korupsi di Indonesia yaitu pendapatan atau gaji tidak mencukupi, penyalahgunaan kesempatan untuk memperkaya diri, penyalahgunaan kekuasaan untuk memperkaya diri . Menurut Dr. Sarlito W. Sarwono, aspek dorongan dari dalam diri sendiri berupa keinginan, hasrat, kehendak dan sebagainya, sedangkan aspek rangsangan dari luar berupa dorongan keluarga, teman-teman dan kerabat lainnya, adanya kesempatan, kurang kontrol. ${ }^{18}$

Tindak pidana korupsi tidak memandang kelas, beberapa profesi penyelenggara negara dan swasta terlibat melakukan tindak pidana korupsi. Dari beberapa data dibawah ini dapat dilihat sebagai contoh profesi mana saja yang melakukan tindak pidana korupsi dan apa penyebabnya :

\section{Dewan Perwakilan Rakyat.}

Persoalan mentalitas dan moralitas adalah hal yang sangat mendasar yang membuat anggota DPR korupsi. Sebagai sebuah lembaga yang mempunyai posisi tawar yang bagus sesuai dengan fungsi dan kewenangannya anggota DPR seperti merasa diatas angin, dan mempunyai pengaruh yang besar terhadap penyelenggaraan Negara. Lembaga DPR mempunyai 3 Fungsi, yang mana fungsi ini tidak mungkin dimiliki lembaga lain, fungsi tersebut meliputi : fungsi legislasi : dilaksanakan sebagai perwujudan DPR selaku pemegang kekuasaan membentuk undang-undang, fungsi anggaran : dilaksanakan untuk membahas dan memberikan persetujuan atau tidak memberikan persetujuan terhadap rancangan undang-undang tentang APBN yang diajukan oleh Presiden.fungsi pengawasan dilaksanakan melalui pengawasan atas pelaksanaan undang-undang dan APBN.

Tiga faktor diatas yang terkait dengan fungsi DPR adalah hal yang menyebabkan lembaga DPR termasuk lembaga terkorup sekarang ini. Berbagai kasus korupsi yang terjadi di DPR tidak mungkin hanya DPR yang terlibat, jelas ada peran Eksekutif yang turut berperan dalam berbagai proyek yang di Korupsi. Kongkalingkong anatara eksekutif dan legislatif ini sudah menjadi rahasia umum, jadi kalau pejabat sekelas Presiden tidak tahu telah

18. Op.Cit Sukron Kamil hlm 31-32. 
terjadi penyelewengan APBN itu memang sangat mustahil. ${ }^{19}$

\section{Kepala Daerah :}

Selain defisit integritas, ada tiga faktor pendorong korupsi bagi kepala daerah. Pertama, kepentingan ongkos politik. Hal ini terjadi sebagai imbas dari besarnya biaya politik yang sudah dikeluarkan selama pemilihan kepala daerah. Kedua, terbukanya peluang (celah dalam regulasi) melakukan korupsi. Ketiga, lemahnya pengawasan di tingkat daerah. Keberadaan Badan Pengawas Daerah (Bawasda) serta Badan Pengawas Keuangan dan Pembangunan (BPKP) di daerah juga tidak berjalan optimal karena sifat kerjanya yang pasif, hal ini diperparah dengan tidak berjalannya pengawasan dari parlemen daerah. ${ }^{20}$

\section{Korupsi di Sektor Swasta :}

Sumber utama terjadinya praktik korupsi di sektor swasta adalah suap menyuap. Praktik suap menyuap tersebut terjadi ketika dunia bisnis bersinggungan dengan pejabat pemerintah, pegawai negeri, ataupun anggota partai politik.

\section{Korupsi di Hotel Prodeo "dipenjara" :}

Ada 5 (lima) pola korupsi yang terjadi di lapas atau rutan:

\footnotetext{
${ }^{19}$. jinatha.blogspot.co.id/2012/06/faktorpeneyebab-korupsi-di-dpr.html

${ }^{20}$. Emerson Yuntho. Negeri di Kepung

KORUPTOR (Malang : Intrans Publishing, 2011hlm 54-55
}

Pertama, pemberian perlakuan dan fasilitas khusus selama dalam tahanan. Dengan membayar sejumlah uang kepada oknum petugas, napi akan mendapatkan perlakuan berbeda dengan napi lain. Kedua, pemberian jasa keamanan, secara umum kondisi rutan atau lapas di Indonesia tidaklah seaman yang dibayangkan. Ketiga, jalan-jalan keluar dari penjara tanpa izin. Keempat, pemberian remisi. Salah satu jalan cepat yang dapat digunakan napi agar segera menghirup udara bebas adalah pemberian remisi (pengurangan hukuman). Kelima, pungutan untuk tamu atau pengunjung, sudah menjadi rahasia umum ketika ada keluarga atau tamu yang ingin mengunjungi napi ternyata ada pungutan tidak resmi.

\section{Pembalak Liar Sebagai Koruptor :}

Praktek korupsi yang dilakukan perusahaan Hak Pengusahan Hutan (HPH) dan Hutan Tanaman Industri (HTI) tidak lepas dari peran oknum pemerintah dan celah aturan hukum yang kurang tegas. Pembalakan liar tidak mungkin terjadi sendirinya. Ada pihak lain yang membuka jalan atau membiarkan terjadinya pembalakan liar. Membuka jalan diartikan sebagai member izin atau melegalkan sesuatu yang tidak legal, sedangkan membiarkan, diartikan sebagai menutup mata terhadap praktek ini, mesikupn pejabat tersebut memiliki kewenangan untuk melakukan 
pengawasan atau penindakan secara hukum. ${ }^{21}$

\section{Illegal Logging Yang Dilegalkan :}

Banyaknya kasus illegal loging yang dibebaskan oleh pengadilan, setidaknya menunjukkan bahwa upaya pemberantasan illegal loging yang dilakukan pemerintah bersama jajaran dibawahnya ternyata tidak didukung maksimal oleh pengadilan. Jika pemerintah dinilai giat dalam memberantas illegal loging, pengadilan justru giat dalam membebaskan pelaku illegal loging. ${ }^{22}$. Pembebasan pelaku illegal loging dari jeratan hukum dimungkinkan besar karena adanya pemberian sejumlah uang kepada aparat penegak Hukum.

Penerapan system pembuktian terbalik ini menurut keterangan seorang Comission Against Coruption Hongkong cukup efektif untuk memberantas tindak pidana korupsi karena seseorang akan takut melakukan korupsi sebab akan sulit baginya memberikan penjelasan yang memuaskan kepada aparat penegak hukum tentang sumber kekayaannya itu diperoleh dengan cara tidak sah. ${ }^{23}$ Sistem pembuktian terbalik terhadap tindak pidana korupsi ini sudah dianut dan berhasil dilaksanakan di beberapa negara seperti Hongkong, Malaysia dan Singapura.

Bagaimana proses pembuktian terbalik itu ? Pembuktian terbalik

${ }^{21}$. Ibid hlm 63 dan 64.

${ }^{22}$. Ibid hlm 70 .

23. Harian Kompas tanggal 14 April 2014. pertama kali diterapkan dalam kasus Bhsym.A, mantan pejabat Pajak dan Bapenas. Awlanya PPATK mencurigai transaksi keuangan di rekening istri dan dua putrinya Bhsym. A sejak tahun 2004 hingga tahun 2010 mencapai Rp 932 Miliar. Total saldo diseluruh rekening saat di blokir sekitar Rp 65 Miliar. Penyidik lalu meminta keterangan yang bersangkutan dari mana asal usul kekayaannya, namun dia tidak mampu menjelaskan. Dari harta Rp 65 Miliar itu penyidik hanya mampu membuktikan korupsisenilai Rp 1 Miliar (suap dari seseorang), sisanya penyidik menjerat dengan pasal pencucian uang. Di Pengadilan, Hakim meminta Bhsym membuktikan keabsahan hartanya yang dia sebut hasil berbagai usaha. Bhsym lalu menunjukan dokumen-dokumen yang dia klaim sebagai bukti usaha. Namun, dalam vonis, Majelis Hakim tidak mengakui seluruh bukti itu lantaran tidak sah menurut hukum. Akhirnya hakim memvonis Bhsyim penjara selama 10 tahun, ditambah denda $\mathrm{Rp} 250$ juta, subside 3 (tiga) bulan kurungan. Tidak hanya itu, hartanya senilai $\mathrm{Rp}$ 60,9 Miliar ditambah 681, 147 dollar AS, dirampas untuk negara karena terbukti hasil tindak pidana. ${ }^{24}$

Dalam pembuktian terbalik seperti yang telah dijelaskan diatas, apabila ditemukan harta kekayaan terdakwa walaupun tidak terkait

24.

http://blogmiqbal.blogspot.co.id/2013/03/penerap an-asas-pembuktian-terbalik.html, di download pada tanggal 13 April 2016 pukul 11.29 wib. 
langsung dengan tindak pidana yang sedang disidangkan tetapi si terdakwa tidak dapat menjelaskan asal-usul harta kekayaan tersebut atau harta kekayaan tersebut diperoleh dengan cara-cara yang tidak sah maka hakim dapat merampas harta kekayaannya untuk negara. Putusan untuk merampas harta kekayaan si terdakwa tersebut tidak perlu dilakukan pada sidang tersendi tetapi dapat langsung dilakukan Majelis Sidang pada saat putusannya. Demikian juga untuk eksekusinya, Jaksa Penuntut Umum dapat langsung mengeksekusi baik harta kekayaan yang berhubungan langsung dengan tindak pidana yang sedang ditangani dan/atau harta kekayaan yang diperoleh bukan berdasarkan hak-haknya.

\section{B. Efektivitas Mengungkap Tindak Pidana korupsi Melalui Pembalikan Beban Pembuktian (Pembuktian Terbalik)}

Pembalikan beban pembuktian
atau yang biasanya disebut
pembuktian terbalik biasanya
dilakukan setelah suatu tindak pidana
korupsi yang sudah selesai
penyidikannya dan berkas perkara
sudah dilimpahkan ke kejaksaan. Si
pelaku tindak pidana korupsi sudah
menjadi terdakwa. Dalam pembuktian
terbalik tersebut, terdakwa wajib
memberikan keterangan tentang
seluruh harta bendanya dan harta
benda istri atau suami, anak, dan
harta benda setiap orang atau
korporasi yang diduga mempunyai
hubungan dengan perkara yang
didakwakan. Dalam hal terdakwa

tidak dapat membuktikan tentang kekayaan yang tidak seimbang dengan penghasilannya atau sumber penambahan kekayaannya, maka keterangan tersebut dugunakan untuk memperkuat alat bukti yang sudah ada bahwa terdakwa telah melakukan tindak pidana korupsi.

Dari sisi percepatan pemberantasan korupsi, tentu penerapan mekanisme pembuktian terbalik melalui aturan yang sudah ada saat ini diharapkan akan memberikan pengaruh yang signifikan. Harta kekayaan yang tidak wajar yang dimiliki oleh PNS atau Penyelenggara Negara lainnya, yang pendapatannya dalam era keterbukaan informasi seperi sekarang ini jelas bisa diketahui oleh publik, dan bisa menjadi pintu masuk bagi penegak hukum untuk patut menduga bahwa kekayaannya tersebut didapatkan dari hasil korupsi. Bukankah korupsi telah merampas begitu banyak hak-hak rakyat yang seharusnya dipenuhi. Besarnya kerugian negara yang ditimbulkan dari korupsi seharusnya dapat digunakan untuk membuka lapangan kerja yang merupakan hak asasi setiap warga Negara. Yang ditekankan pembuktian terbalik dalam usaha pemberantasan korupsi bukan pada pelanggaran terhadap hak-hak individual atau pelanggaran terhadap privasi semata, namun sebagai solusi bagi usaha memaksimalkan pemberantasan korupsi untuk tujuan yang lebih besar, yakni kemakmuran dan kesejahteraan rakyat banyak. ${ }^{25}$

${ }^{25}$. http://www.irsangusfrianto.com/p/blogpage 7202. html, di download pada tanggal 12 April 2016 pukul 08.27 wib. 
Koruptor biasanya lihai dan rapi sekali menyembunyikan harta kekayaannya, tetapi aparat penegak hukum tidak boleh kalah dengan koruptor. Aparat penegak hukum harus lebih lihai menyelidiki semua harta kekayaan koruptor disimpan dimana saja, baik di dalam maupun di luar negeri. Yang perlu mendapatkan penyelidikan yang lebih super ekstra apabila harta kekayaan koruptor itu disimpan di luar negeri dengan nama orang lain. Aparat penegak hukum harus bergerak lebih cepat, teliti, semangat dan mempunyai integritas yang tinggi untuk menemukan harta koruptor yang disimpan dimana saja. Apabila ditemukan ada penyimpanan harta koruptor baik yang terkait dengan korupsi yang sedang ditangani maupun korupsi sebelumnya atas nama orang lain, maka orang tersebut harus dikenakan pasal-pasal pencucian uang. Diarahkan bagi siapa saja jangan mau menyimpan harta kekayaan orang lain untuk simpan di Bank nya.

Para koruptor yang dituding melakukan tindak pidana korupsi atau gratifikasi sering membantah bahwa tidak ada menerima uang terkait perbuatan korupsi atau gratifikasi, kalau dituduh korupsi/gratifikasi selalu menyatakan mana buktinya, dan pada umumnya yang menuduh melakukan korupsi biasanya secara tertutup karena bila tidak benar dapat dituntut di muka pengadilan dengan tuduhan melakukan fitnah atau penghinaan, maka tuduhan melakukan korupsi lewat surat kaleng yang mencantumkan nama samara dengan alamat palsu, dan jika dipanggil jika dipanggil tidak adatang. ${ }^{26}$

Untuk membuktikan perbuatan korupsi cukup sulit, diperlukan waktu yang lama untuk mengungkapnya. Perbuatan korupsi ada rasa bau tetapi tidak tahu siapa yang mengeluarkannya, kesulitan-kesulitan membongkarnya antara lain disebabkan :

\section{Tutup Mulut :}

Selama pembagiannya dianggap wajar sesuai kedudukannya dalam proyek tersebut akan tutup mulut dan tidak akan membuka masalah penyelewengan pada siapa pun, hanya saja bila pembagiannya dirasakan tidak wajar inilah yang suka membuka masalah penyelewengan tersebut baik leweat surat kaleng atau menyampaikan kepada orang lain.

\section{Empat Mata :}

Pemberian uang korupsi dari masyarakat kepada aparat pemerintah maupun sesama aparat selalu dilakukan empat mata, dengan maksud bila terjadi sesuatu tidak ada pihak lain yang menyaksikannya atau tidak ada alat buktinya. ${ }^{27}$

Mengungkap suatu tindak pidana korupsi dengan pembuktian terbalik dimulai dari ditemukannya suatu tindak pidana korupsi, dilanjutkan dengan penyidikan untuk membuat berkas perkara, setelah berkas perkara dinyatakan lengkap (P-21) kemudian berkas

${ }^{26}$. Monang Siahaan, Op. Cit hlm 116

27 . Monang Siahaan, Op. Cit hlm 122. 
perkara dilimpahkan ke Kejaksaan. Setelah berkas perkara berada di pihak Kejaksaan, aparat Kejaksaan dapat melakukan pemeriksaan tambahan dengan mewajibkan si terdakwa memberitahukan dan membuktikan seluruh harta kekayaan yang dimilikinya. Harta kekayaan si terdakwa kemudian diteliti asal-usulnya. Apabila ditemukan harta kekayaan tersebut diduga diperoleh dari korupsi/gratifikasi, meskipun bukan dari tindak pidana korupsi yang sedang ditangani, maka Kejaksaan dapat melakukan penyidikan baru terhadap harta kekayaan tersebut karena sesuai pasal Undang-Undang Nomor 16 Tahun 2004 tentang Kejaksaan Republik Indonesia, selain Kepolisian dan Komisi Pemberantasa Korupsi (KPK), Jaksa juga merupakan penyidiki tindak pidana korupsi. Melalui cara pembuktian terbalik ini, efektivitas untuk mengungkap suatu tindak pidana korupsi yang baru diharapkan berhasil baik kuantitasnya maupun kualitas tindak pidana korupsi tersebut.

\section{Efektivitas Mengungkap Tindak Pidana korupsi Melalui Laporan Harta Kekayaan Penyelenggara Negara (LHKPN)}

\section{Mengungkap Tindak Pidana Korupsi dari Harta Kekayaan Penyelenggara Negara Fantastis yang Dilaporkan :}

Pengungkapan tindak pidana korupsi melalui laporan harta kekayaan penyelenggara negara (LHKPN) bisa dilakukan sebelum ditemukan adanya suatu tindak pidana korupsi. Laporan harta kekayaan tersebut terdiri dari harta tidak bergerak (tanah dan bangunan), harta bergerak (alat transfortasi dan mesin lainnya), usaha-usaha, perhiasan, surat berharga, uang tunai/deposito dan tabungan, piutang dan hutang. Semua harta kekayaan ini diperhitungkan dari penghasilan yang sah dan pengeluaran seorang penyelenggara negara. Seberapa banyak penghasilannya yang sah dikurangi seberapa banyak pengeluarannya setiap tahunnya termasuk pajaknya itulah merupakan harta kekayaannya, ditambah lagi misalnya ada harta /kekayaan hiba atau warisan atau harta lainnya yang diperoleh secara sah.

Cara mengungkapkan bahwa telah terjadi tindak pidana korupsi melalui laporan harta kekayaan penyelenggara negara dapat dimulai apabila ada seorang penyelenggara negara yang melaporkan sejumlah harta kekayaannya dan dari sejumlah harta kekayaannya itu ada harta kekayaan yang mencurigakan dan sangat fantastis jumlahnya yang tidak mungkin di dapat dari penghasilannya yang sah. Berdasarkan adanya harta kekayaan yang sangat fantastis tersebut, komisi pemeriksa sesuai dengan kewenangannya harus mewajibkan dengan paksaan kepada sipenyelenggara negara itu untuk mengklarifikasi harta kekayaannya yang fantastis tersebut, apabila tidak bisa membuktikan bahwa harta 
kekayaannya tersebut diperoleh dari penghasilan yang sah maka komisi pemeriksa menyerahkan temuannya kepada Komisi Pemberantasan Korupsi (KPK) dan KPK dapat memulai melakukan pemeriksaan kepada penyelenggara negara tersebut dengan sangkaan melakukan tindak pidana korupsi, gratifikasi atau pencucian uang. Melalui LHKPN yang fantastis tadi, KPK dapat melakukan penyelidikan/penelusuran dari mana, kapan dan bagaimana caranya penyelenggara negara mendapatkan harta kekayaan tersebut.

Banyak penyelenggara negara yang mempunyai harta kekayaan melebihi penghasilannya yang sah, tidak jarang mereka menyebutkan bahwa harta kekayaannya yang fantastis tersebut diperoleh dari hiba atau dari warisan orang tua atau bahkan dari hasil usaha (bisnis). Hiba dari mana dan kapan di hibakan, kapan dan bagaimana pula orang tuanya mewariskan harta kekayaan kepada penyelenggara negara tersebut, apalagi diketahui bahwa orang tuanya tidak mempunyai harta kekayaan yang banyak, kapan mereka melakukan bisnis, bisnis apa? Komisi pemeriksa seharusnya jangan percaya begitu saja, karena itu akal-akalan penyelenggara negara untuk mengelabuhi. Komisi pemeriksa harus meneliti dan mewajibkan kepada penyelenggara negara itu membuktikan bahwa benar-benar telah memperoleh hiba dari seseorang dan mendapatkan warisan dari orang tua.
2. Mengungkap Tindak Pidana Korupsi dari Harta Kekayaan Penyelenggara Negara yang Tidak Dilaporkan (Disembunyikan).

Apabila penyelenggara negara tidak melaporkan harta kekayaannya dalam LHKPN dan akhirnya terungkap di tempat lain menyimpan harta kekayaannya tersebut misalnya di Panama Papers, maka Komisi Pemeriksa bisa beranggapan bahwa penyelenggara negara tersebut memiliki niat jahat dengan menyembunyikan harta kekayaannya. Bisa saja harta kekayaannya yang ada di Panama Papers tersebut di peroleh dengan cara-cara yang tidak sah (tidak benar), misalnya dari tindak pidana korupsi, gratifikasi atau pencucian uang. Oleh karena itu, seluruh harta kekayaan penyelenggara negara yang di simpan di Panama Papers atau di tempat lain harus diselidiki asal usulnya dan melalui harta kekayaan yang di Panama Papers dan di tempat lain itu bisa menjadi pintu bagi KPK untuk mengungkap apakah penyelenggara negara tersebut sudah melakukan tindak pidana korupsi, gratifikasi atau pencucian uang.

Banyak nama-nama pejabat Indonesia yang terdaftar di Panama Papers, Komisi Pemberantasan Korupsi harus tetap memantau perkembangan nama-nama penyelenggara negara yang masuk dalam Panama Papers. Langsung atau tak langsung, KPK harus mengikuti perkembangannya, apakah lewat 
LHKPN atau lewat lainnya. KPK akan bisa masuk lewat pintu korupsi sehingga perlu bukti yang akurat. KPK harus tetap skeptis dan kritis menanggapi nama-nama yang masuk dalam Panama Papers, kendati pejabat negara melaporkan harta kekayaannya dalam LHKPN, bukan jaminan tidak melakukan korupsi. LHKPN bukan jaminan tak terjadi korupsi. LHKPN bukan legitimasi tak terjadi korupsi. Dengan kata lain, ada tidak ada LHKPN, KPK tetap menaruh perhatian atas potensi korupsi. ${ }^{28}$ Dengan adanya LHKPN saja dimungkinkan penyelenggara negara (pejabat) melakukan tindak pidana korupsi, apalagi kalau tidak adanya LHKPN, pejabat seenaknya saja mencari uang dengan cara apapun yang mengatasnamakan jabatannya dan menyimpan harta kekayaannya dimana saja tanpa perlu melaporkannya.

Data Panama Papers bisa menjadi pintu masuk untuk menelusuri adanya tindak pidana dari nama-nama yang disebut di dalamnya, selain penegak hukum lembaga pengawas keuangan juga bisa memanfaatkan data tersebut, pasalnya bisa bermacam-macam, termasuk tindak pidana korupsi dan pencucian uang. ${ }^{29}$ Jika ada ketidaksesuaian dengan pelaporan selama ini oleh orang-orang yang namanya disebut dalam Panama Papers (LHKPN bohong/ yang tidak benar), orang-orang tersebut harus ditindak, karena dengan

28. Harian Kompas tanggal 19 April 2016 hlm 5.

${ }^{29}$. Harian Kompas tanggal 8 April 2016 hlm 1. tidak melaporkan dengan jujur harta kekayaan penyelenggara negara tersebut, merupakan indikasi ada niat dari penyelenggara negara tersebut untuk tidak membayar pajak dan dimungkinkan pula harta kekayaan yang disimpan di Panama Papers atau di tempat (Bank) lain diperoleh dari hasil korupsi atau tindak pidana lainnya.

Yang menjadi pertanyaan adalah mengapa penyelenggara negara menyimpan uangnya di Panama Papers dan mengapa harta kekayaannya yang ada di panama papers tidak dilaporkan dalam LHKPN ?. Apakah hanya untuk menghindari membayar pajak atau ketakutan harta kekayaannya yang disimpan di Panama Papers akan ketahuan diperoleh dengan cara melanggar hukum? Kalau hanya menghindari supaya tidak membayar pajak, itu kecil kemungkinan karena pajak yang harus disetorkan ke kas negara tidaklah berarti (hanya sedikit) dibandingkan dengan keuntungan yang diperoleh dari deposito Bank atau hasil usaha dari sejumlah harta kekayaan yang disimpan di Panama Papers. Kemungkinan besar harta kekayaan penyelenggara negara yang disimpan di Panama Papers di dapat dari suatu cara yang melanggar hukum, oleh karena itu KPK bekerja sama dengan Direktorat Pajak dan Komisi Pemeriksa harta kekayaan penyelenggara negara harus menyelidiki / menelusuri seluruh harta kekayaan pejabat / penyelenggara negara yang 
menyimpan harta kekayaannya di Panama Papers.

Penyelenggara negara yang tidak melaporkan sebagian harta kekayaannya dan ketahuan menyimpan di Panama Papers atau di tempat (Bank) lain sudah dapat dikatakan ada indikasi bahwa si penyelenggara negara telah melakukan tindak pidana, baginya harus diterapkan azas praduga bersalah (Presumption of guilt). Oleh karena itu, jangan raguragu memeriksa si penyelenggara negara baik sebagai saksi dan selanjutnya bisa saja ditingkatkan menjadi tersangka. Khusus untuk pejabat (penyelenggara) negara yang menyimpan harta kekayaannya dalam bentuk usaha di Panama Papers atau di negaranegara surga pajak lainnya, mereka harus dilarang menyimpan hartanya di luar Indonesia dan jangan diberikan pengampunan pajak (tax amnesty). Sudah seharusnya aparat penegak hukum bergerak melakukan proses hukum terhadap mereka. gaji tidak mencukupi, penyalahgunaan kesempatan, penyalahgunaan kekuasaan untuk memperkaya diri. Aspek dorongan dari dalam diri sendiri berupa keinginan, hasrat, kehendak, sedangkan aspek rangsangan dari luar berupa dorongan keluarga, teman-teman dan kerabat lainnya. Selain itu dikarenakan adanya kesempatan dan juga kurang kontrol.

2. Efektivitas pembalikan beban pembuktian (pembuktian terbalik) dan Laporan Harta Kekayaan Penyelenggara Negara sangatlah efektif dalam mengungkap suatu tindak pidana korupsi karena penyelenggara (pejabat) negara harus membuktikan semua harta kekayaannya diperoleh dari mana. Apabila tidak dapat membuktikan bahwa harta kekayaannya diperoleh dari penghasilan yang sah, maka menjadi pintu bagi aparat hukum untuk memulai penyelidikan yang selanjutnya bisa ditingkatkan menjadi penyidikan.

\section{B. Saran :}

\section{PENUTUP}

\section{A. Kesimpulan :}

1. Tindak pidana korupsi akhir-akhir ini semakin banyak terjadi di Indonesia karena moral yang tidak baik dari pelaku untuk menumpuk kekayaan bagi keluarganya, kelompok atau golongannya sendiri. Ada juga yang berpendapat indikasi yang menyebabkan meluasnya korupsi di Indonesia yaitu pendapatan atau
1. Agar rekrutmen setiap aparat sipil negara dan aparat militer lebih selektif terutama dari aspek moralnya, bila perlu harus menandatangani pakta integritas bahwa apabila suatu saat terbukti melakukan korupsi maka harus dihukuman berat dan dipecat dari instansinya serta mengganti seluruh kerugian. Tetapi, peningkatan kesejahteraan dengan cara menaikan gaji dan tunjangan juga perlu dilakukan secara 
berkala, memberikan award kepada yang berprestasi

2. Agar pembalikan beban pembuktian (pembuktian terbalik) dan Laporan Harta Kekayaan Penyelenggara Negara tetap diberlakukan dalam mengungkap suatu tindak pidana korupsi. Aparat penegak hukum yang menangani pembuktian terbalik harus jujur, teliti, cerdas dan memiliki moralitas yang tinggi. Demikian juga Komisi Pemeriksa yang menangani laporan harta kekayaan negara harus mempunyai integritas tinggi, kredibel, jujur tidak mau disuap serta jangan gampang percaya kepada keterangan penyelenggara negara yang melaporkan harta kekayaannya.

\section{DAFTAR PUSTAKA}

\section{A. Buku-Buku}

Binoto Nadapdap, Korupsi Belum Ada Matinya, Permata Aksara, Jakarta

Djoko Prakoso, Pembaharuan Hukum Pidana Di Indonesia, Penerbit : LIBERTY, Jogjakarta 1987.

Elsi Kartika Sari dan Advendi Simangunsong, Hukum Dalam Ekonomi, Edisi Kedua, Penerbit PT Gramedia Widiasarana Indonesia, Jakarta, 2008.

Emerson Yuntho, Negeri di Kepung Koruptor, Instran Publishing, Malang 2011.

Etty Indriati, Pola dan Akar Korupsi, Menghancurkan Lingkaran Setan Dosa Publik, PT Gramedia Pustaka Utama, Jakartta 2002.
J.Danang Widoyoko, Oligarki dan Korupsi Politik Indonesia, Strategi Memutus Oligarki dan Reproduksi Korupsi Politik, Setara Press Malang 2013.

Jur Andi Hamzah, Pemberantasan Korupsi Melalui Hukum Pidana Nasional dan Internasional, PT RajaGrafindo Persada, Jakarta 2007.

Mahrus Ali, Asas, Teori \& Praktek Hukum Pidana Korupsi, UII Press Jogjakarta 2013.

Moeljatno, Asas-Asa Hukum Pidana, Penerbit Rineka Cipta 2008.

Monang Siahaan,Korupsi Penyakit Sosial Yang Mematikan,Penerbit:Elex Media Komputindo, 2013.

\section{B. Perundang-Undangan}

Undang-Undang Nomor 31 Tahun 1999 tentang Pemberantasan Tindak Pidana Korupsi.

Undang - Undang Nomor 20 Tahun 2001 tentang Perubahan atas UndangUndang Nomor 31 Tahun 1999 tentang Pemberantasan Tindak Pidana Korupsi

\section{Internet / karya ilmiah}

Surat Kabar Jawa Pos 4 Desember 2013.

https://www.facebook.com/Komunit asAntiKorupsiMutasi/posts/1230072 $\underline{34530680}$ di download tgl 25 September 2015 pkl 09.30 wib.

faturohmanalbantani.blogspot.co.id/2 011/01-ciri-ciri-korupsi-sebab-danakibat-html. didownload pada tanggal 22 Maret 2016 pukul 16.20 wib. 